\title{
Manufacturing "Terrorists": Refugees, National Security, and Canadian Law
}

\author{
Sharryn J. Aiken
}

\section{Abstract}

In the first part of a two-part article, the author critically evaluates the anti-terrorism provisions of Canada's Immigration Act. The impact of these provisions on refugees is the focus of the essay, but her observations are relevant to the situation of other categories of non-citizens as well. The inquiry begins by considering international efforts to address "terrorism," the relevance of international humanitarian law to an assessment of acts of "terror," and the nature of contemporary discourse on "terrorism." Next, the evolution of the current admissibility provisions in Canadian immigration law, with particular reference to refugee policy and national security, is reviewed. A brief discussion of current policy directions concludes part 1.

\section{Résumé}

Dans ce premier volet (d'un article à deux volets), l'auteure se livre à une évaluation critique des dispositions antiterroristes de la loi canadienne sur l'immigration. Elle se concentre sur l'impact de ces dispositions sur les réfugiés, mais ses remarques sont aussi valables pour d'autres catégories de non-citoyens. L'enquête examine, avant tout, les efforts déployés au niveau international pour contrecarrer "le terrorisme ", la pertinence de la loi humanitaire internationale dans le cadre de l'évaluation des actes de "terreur ", et la nature du discours contemporain sur le "terrorisme ». Seront examinés ensuite, la façon dont ont évolué les dispositions courantes de la loi canadienne sur l'immigration, la notion d'admissibilité, avec une référence particulière à la politique sur les réfugiés et la sécurité nationale. Pour conclure cette première partie, on trouvera une brève discussion sur les tendances dans la politique actuelle.
What can we make of the fact that terrorism has become such a shifty category that yesterday's terrorists are today's Nobel Peace Prize winners? ... [W] e question the very possibility of defining and thereby giving a satisfactory account of, the facts categorized as terrorism ... Far from being a benign or gratuitous labelling exercise, the stark issue of who has the power to define another as a terrorist has obvious moral and political implications ... The various types of fictionalization-representation by the media, political manipulation, academic definitions, the imaginary archetype ... find their genesis and nourishment in the play with meaning and confusion of contexts inherent in the word "terrorism."

-J. Zulaika and W. Douglas, Terror and Taboo'

\section{Introduction}

lthough numerous states and movements have used
violence to achieve specific political goals through-
out history, ${ }^{2}$ the use of the word terrorism ${ }^{3}$ has relatively recent origins. The term was coined to describe a specific phase of the French Revolution known as the Reign of Terror, when the Jacobins initiated a campaign of repression in which at least 17,00o French citizens were guillotined and many thousands more imprisoned and tortured. ${ }^{4}$ In this context, Mitchell indicates that " $\left.\mathrm{t}\right]$ errorism was perceived as an unspeakable crime-the product of moral depravity or madness."5 "Terrorism" was initially described an exercise of repression by a state against its own citizens, but during the course of the nineteenth and twentieth centuries both the term itself and the measures adopted by states in response to it became increasingly politicized. One need only consider the U.S. description of its retaliatory bombing attacks in Sudan and Afghanistan as "counter-terrorism," or the speeches of Israeli leaders decrying the "terrorist" acts of Palestinians while justify- 
ing gunfire on crowds of Palestinian civilians as "defence," to appreciate how "terrorists" are manufactured for the most cynical and explicitly political purposes.

Canadian officials acknowledge that Canada has never been a major target for "terrorist" attacks. ${ }^{6}$ The government's preoccupation with "terrorism" has focused primarily on the perceived "terrorist" threat posed by refugees and immigrants arriving from non-Western countries. Security intelligence reports confirm the existence of individuals and organizations operating in Canada to support, plan, and mount attacks elsewhere, although open information by no means suggests that the participation rate of immigrants in these activities is proportionally higher than

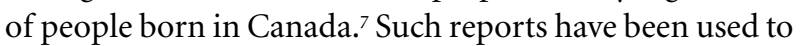
justify a complex web of immigration security measures. While few would dispute the legitimacy of genuine efforts to protect public safety, the problem with many of these measures is that they have cast an unacceptably wide and uneven net. The "terrorist" has become the post-modern substitute for the "vicious class" that nineteenth-century immigration laws constructed as a tool of immigration control. In common with their historical counterpart, antiterrorism provisions in the Immigration Act serve as a cover to legalize the broadest discretion over who gets in and who is permitted to stay.

In 1991 Gorlick commented that the government used its national security policies to exclude those considered to harbour ideological or political views inimical to the liberal democratic values of the Canadian state. ${ }^{8}$ In the postCold War context with its attendant international realignments, this observation no longer provides a full account of immigration security policy. An analysis of current deportation practices suggests that immigration measures aimed at protecting the "security of Canada" are not about rooting out foes of democracy and genuine threats to the nation. They are but one tool, in an increasingly sophisticated arsenal, to contain and manage refugee admissions. ${ }^{9}$ In this regard, not all refugee communities are subjected to the same level of security scrutiny.

As Whitaker explains in his recent discussion of the security dimension of refugee policy, the "systematic political bias of the Cold War has been replaced by a patchwork of specific biases. ${ }^{.10} \mathrm{He}$ points out that the injustices against individuals are just as frequent today, but the "biases are more diffuse." Indeed, under the new order, the designation of certain refugees as "terrorists" serves multiple geopolitical and economic interests. While I agree with Whitaker that racism should not be seen as a sole explanation for government security policy, ${ }^{12}$ current policies do reinforce systemic racism in Canadian law and practice. ${ }^{12}$
A few examples are illustrative. On the one hand, the government introduced expedited screening and emergency evacuation for 5,00o ethnic Albanians fleeing Kosovo in 1999, in spite of the reasonably high level of active support for the Kosovo Liberation Army among the refugee population. ${ }^{14}$ On the other, there was an extremely modest response, implemented only last year, to a humanitarian crisis in Sierra Leone, a country that has suffered a devastating war for the past decade and has produced a massive outflow of refugees. We can also consider the inherent contradiction in a government policy that permits certain diaspora communities to raise funds in support of political causes and organizations in their homelands with impunity, while others risk expulsion from Canada for the very same conduct. In preparation for the World Conference on Racism, the Canadian Council for Refugees noted,

Certain ethnic or national groups are particularly apt to be targeted for extra security checks ... Those who have been found inadmissible or have been kept waiting without a decision being made on a security related provision include significant numbers of Iranians with some association with the Mojahaddin movement and Kurdish people. ${ }^{15}$

In effect, the immigration/national-security apparatus replicates an imperative of exclusion and restriction that pre-emptively and selectively casts some groups of refugees and other non-citizens as "terrorist," "alien," and "other" - people on the periphery whose claims for justice can be ignored. ${ }^{16}$

As Canadian law changes its conception of refugees from victims and survivors to fearsome "terrorists," political activism that is lawful for citizens becomes a basis for expelling non-citizens. The expression of support for a liberation struggle being waged in one's country of origin can be sufficient grounds to be designated a security risk. The Immigration Act accords the same treatment to the mastermind of a hijacking and the person who has raised money in Canada to support an orphanage in her war-ravaged homeland. Refugee claimants seeking asylum and Convention refugees applying for permanent residence may be subjected to security interviews that all too frequently resemble interrogations and for which the individuals arrive unprepared, having been given no notice of the purpose of the interview or their entitlement to be represented by counsel. ${ }^{17}$ Most of the adverse information that the Canadian Security Intelligence Service (csis, or "the Service") collects will be classified on national security grounds and therefore not disclosed to the person concerned. Refugee claimants may be deemed ineligible to even initiate their claims and be divested of the right to a "post-claim review." Subsequent administrative proceedings very often leave 
individuals in a legal limbo while their files await review by department analysts. Once a "security certificate" has been issued, the decision of a single "designated" judge is considered conclusive proof of the allegations against the individual and cannot be appealed. The result will be mandatory detention, followed ultimately by deportation back to the country where the refugee may be at serious risk of persecution, torture, or death. While the numbers of affected individuals are relatively small, the gravity of the issues at stake signal an urgent need for law reform. ${ }^{18}$

The overarching objective of this paper is to provide a critical lens through which the anti-terrorism provisions of Canada's Immigration Act can be evaluated. The impact of these provisions on refugees is the primary focus of this essay, but my observations are relevant to the situation of other categories of non-citizens as well. My inquiry will begin by considering international efforts to address "terrorism," the relevance of international humanitarian law to an assessment of acts of "terror," and the nature of contemporary discourse on "terrorism." Next, the evolution of the current admissibility provisions in Canadian immigration law, with particular reference to refugee policy and national security, will be reviewed. A brief discussion of current policy directions will conclude part 1. In part 2, an analysis of the Federal Court's key decisions dealing with immigration security and refugee exclusion will be examined, highlighting the Court's role in manufacturing and instrumentalizing "terrorists." Before concluding, some preliminary suggestions for navigating the contested representations of "terrorism" will be offered, with a view to restoring human rights for refugees while safeguarding a genuine public interest in security.

\section{"Terrorism": International Initiatives and Contemporary Discourse}

The first international initiative aimed at combating "terrorism" was undertaken in 1937 by the League of Nations. The proposed Convention for the Prevention and Punishment of Terrorism defined "terrorism" as "criminal acts directed against a State and intended or calculated to create a state of terror in the minds of particular persons, or a group of persons or the general public." Only one nation, India, ratified the Convention before the outbreak of the Second World War and the demise of the League of Nations. ${ }^{19}$ In the post-1945 era, the threat of "terrorism" gained increasing prominence on the agendas of the United Nations, and a number of Western states in particular. Between 1968 and 1972, a series of high-profile hijacking incidents against Israeli and Jordanian aircraft, together with the Munich Olympics attack by the Black September Organization, coalesced international concern. ${ }^{20}$ At the same time, however, recognition of the legitimacy of anti-colonial (and sometimes violent) struggles against oppressive regimes (e.g., South Africa, Mozambique, and Palestine) was becoming increasingly important throughout the Third World. Through a series of resolutions adopted during the first decades of the United Nations, the abstract principle of self-determination as initially articulated in the un Charter had been upgraded to an invocable right of peoples. ${ }^{21}$ Schrijver describes how this development culminated in the Decolonisation Declaration of 1960, in the identical Article 1 of the International Covenants of Human Rights of 1966, providing that "All peoples have the right to self-determination," and in the firm recognition accorded to self-determination in the 1970 Declaration of Principles of International Law Governing Friendly Relations among States. ${ }^{22}$ In this context, any effort to define "terrorism" was fraught with difficulty. As noted by Higgins, "[i]f the West was nervous that a definition of terrorism could be used to include 'state terrorism', the third world was nervous that any definition which emphasized non-State actors would fail to differentiate between terrorism properly so called, and the struggle for national liberation." ${ }^{23}$ When the draft Convention on the Prevention of Terrorism, sponsored by the United States, was introduced at the United Nations in 1972, a bitter debate ensued between First World and Third World nations on the merits of a categorical ban on the use of violence. The draft Convention was rejected. ${ }^{24}$ In the intervening years, the United Nations has attempted to achieve a fine balance between these competing concerns, through a series of strongly worded resolutions condemning "all acts, methods and practices of terrorism" ${ }^{25}$ on the one hand, and on the other, by promulgating treaties that deliberately avoid umbrella definitions in favour of proscribing specific and defined criminal misconduct. Developments in international humanitarian law, discussed below, represent a parallel response to the question of national liberation wars.

To date, the United Nations has developed eleven separate agreements prohibiting, among other things, aircraft hijacking, aircraft sabotage, attacks against ships and fixed platforms in the ocean, attacks at airports, violence against officials and diplomats, hostage-taking, the use of unmarked plastic explosives, terrorist bombings (excluding, in certain cases, activities committed within a single state) and, most recently, the financing of terrorist offences. ${ }^{26}$ Regional bodies have adopted similar agreements. ${ }^{27}$ The essential goal of the treaties is to elevate the specified offences to the status of "international crimes," ensuring prosecution of the accused by imposing upon signatory states 
the alternative obligation to extradite or submit the accused for prosecution to the appropriate national authority. The new International Criminal Court (ICC), a separate but complementary initiative, will have jurisdiction over international crimes including genocide, crimes against humanity, war crimes, and aggression-whether committed by states or insurgent groups. However, the Rome Statute does not identify "terrorism" among the distinct categories of crimes within the court's jurisdiction.$^{28}$ With the exception of the crime of aggression, which remains undefined, pending adoption of an agreed definition, the treaty defines each of the crimes with specific reference to illegal acts. ${ }^{29}$ It deserves mention that the Rome Statute includes detailed provisions for individual and "superior" criminal responsibility. In this regard, mere membership in an organization-in the absence of a nexus to the commission of an offence, or in the case of superior officers, in the absence of personal command responsibility for their subordinates who committed an offence-is not a crime under the Rome Statute..$^{30}$

The inability of states to arrive at a common consensus on the meaning of the term terrorism has not prevented international bodies from condemning it, nor has it prevented states from criminalizing specific acts. The $1996 \mathrm{G} 8$ Ministerial Conference on Terrorism adopted a series of measures that made no attempt to define terrorism..$^{31}$ Instead the agreed text aimed at facilitating extradition arrangements and clamping down on criminal use of the Internet and "camouflage" charities involved in illicit transborder fundraising. ${ }^{32}$ Before the meeting, President Clinton identified terrorism as

$[t]$ he greatest security challenge of the twenty-first century ... We cannot have economic security in a global economy unless we can stand against those forces of terrorism. The U.S. will lead the way and we expect our allies to walk with us hand in hand. ${ }^{33}$

In more concrete terms, Canada's Criminal Code identifies discrete offences involving aircraft, international maritime navigation, internationally protected persons, nuclear material, and hostage taking, as well as war crimes and crimes against humanity, all of which may be subject to Canadian prosecution, regardless of where the offence was committed. ${ }^{34}$ The newly implemented Crimes against $\mathrm{Hu}-$ manity Act ensures that refugees who have committed such crimes may be subject to domestic prosecution. ${ }^{35}$ On the other hand, membership in an organization has not been a crime in Canada since the imposition of the War Measures Act against the Front de libération du Québec during the October crisis thirty years ago. ${ }^{36}$ A minority of countries, including Italy, Portugal, and Turkey, have enacted legislation making it a crime for citizens and non-citizens alike to belong to a "terrorist" organization, to provide support or recruit for a "terrorist" organization. It is noteworthy that the Italian Court of Appeal sustained convictions for the Palestinians accused of hijacking the Italian cruise ship Achille Lauro in 1985 but found that only the small, armed nucleus of the Palestine Liberation Front that conceived and carried out the hijacking was an "armed band" ("international terrorist organization") within the meaning of Italy's penal code. Neither the Palestine Liberation Front nor the Palestine Liberation Organization as a whole could be considered criminal organizations, because their essential objective was the liberation of Palestine. ${ }^{37}$ Domestic laws in Germany, the United Kingdom, and the United States identify "terrorism" itself as a crime but include a precise definition of the term for the purpose of applying the law. The majority of countries responding to a Counsel of Europe survey in 1991 indicated that they had no special antiterrorism legislation. ${ }^{38}$

While the academic literature on "terrorism" includes a proliferation of definitions, the consensus among many authors is that there is no universally or even generally accepted definition. ${ }^{39}$ Schmid reports that 109 different definitions of the term international terrorism were advanced between 1936 and 1981, ${ }^{40}$ and more have appeared since..$^{41}$ Although there seems to be agreement that "terrorism" involves the threat or use of violence, Lambert indicates that differences in definition range from the semantic to the conceptual. ${ }^{42}$ The term has been used as a synonym for "rebellion, street battles, civil strife, insurrection, rural guerrilla war, coups d'état and a dozen other things," with the result that it has "become almost meaningless, covering almost any, and not necessarily political, act of violence." ${ }^{43}$ Levitt suggests that the effort to formulate a widely acceptable definition is akin to the search for the Holy Grail." ${ }_{4}$ Commenting on the initiatives undertaken by the United Nations over the years, Higgins emphasizes that " $\mathrm{t}$ ] errorism is a term without legal significance ... it is at once a shorthand to allude to a variety of problems with some common elements, and a method of indicating community condemnation for the conduct concerned." ${ }^{45}$ Commenting on the initial definition contained in the League of Nations Convention, Borricand observes that this initiative "has been much criticized and quite rightly so." ${ }^{46} \mathrm{He}$ elaborates, "Indeed, defining terrorism by the terror it causes is a tautology; speaking of criminal acts is remarkably vague, since the notion of crime varies from one State to another; and lastly, classing as terrorism only those acts that are directed at a State ... is a very restrictive idea ..." ${ }_{47}$ 
In the face of this definitional quagmire, the use of "terrorist" as a conceptual category in the absence of any qualification of constituent elements, must be seen for what it is: a highly charged political position embedded in the particularity of a given cultural, social, and tactical context. ${ }^{48}$ Chomsky identifies the political filters employed to cast the Kurds as "marxist and terrorist," while characterizing the Turkish state as a "secular democracy beleaguered by terrorism," 49 in support of this thesis. Challenging the definitions of "terrorism" exploited by the "terrorism industry" of Western states, quasi-private institutes, and private security firms, Herman and O’Sullivan assert,

If . . . the West has been able to label the world's rebels in Indochina, Indonesia, the Philippines, South Africa, Central America, and other places as "terrorists," and the West and its proxies as engaging in "counterterror," this is a propaganda achievement of historic dimensions. It is also the ultimate Orwellian transformation: the victims are made the terrorists, whereas the terrorists are the alleged victims driven to a counterterror response..$^{50}$

In a similar vein, Falk underscores the extent to which the language of "terrorism" has been enlisted in the service of partisan causes that lie at the root of contemporary geopolitics. When Western states criminalize popular movements that have been banned by ruling elites in their countries of origin, very often the main patterns of conflict are actually reinforced. ${ }^{51}$ Support for Falk's analysis is found in two recent examples. External support became a critical component of the ANC's ultimate success in overthrowing the apartheid regime in South Africa. On the other hand, when the United States proscribed the Liberation Tamils of Tamil Eelam (LTTE) as a "foreign terrorist organization" in 1997, the prospects for initiating peace talks and bringing an end to the protracted war in Sri Lanka deteriorated. It is interesting to contrast the response of a spokesperson for the Sri Lankan foreign office, hailing the American ban on the LTTE as "a victory for Sri Lanka's foreign policy," with the concern expressed by moderate critics that the U.S. policy would thwart attempts to bring the movement into the democratic mainstream, forcing it to become more intransigent. ${ }^{52}$ When Western counter-terrorism policies quell all prospects for external dissent, fundraising, and mobilization, legitimate liberation struggles are further marginalized, leaving even less space for non-violent, political strategies.

Returning to the question of defining "terrorism," the adage often cited that crystallizes the problem is, One person's freedom-fighter is another's terrorist. The context of the international debate has been limited to non-state actors. Even the most recent treaties on the suppression of terrorist bombings and financing are directed narrowly at activities committed against states and their populations, but not by states. In this regard, Chadwick notes that the language used in efforts toward anti-terrorist codification is a manifestation of ideological solidarity on the part of some Western states. She asserts,

States have yet to target themselves for codified sanction for acts of terrorism, whether such acts are state-sponsored, statesupported, or state-conducted. This omission is particularly egregious when viewed in the light of the many state mechanisms of public control which may work to provoke societal violence. This disregard of at least one-half of the equation required to solve the problem of political violence makes it highly possible that state-centric solutions arrived at are in error in both approach and effect. ${ }^{53}$

For Chadwick the problem isn't the intrinsic nature of the term terrorism, but rather the offence-specific and piecemeal nature of the un treaties. While acknowledging the conceptual and definitional pitfalls, she advocates a more even-handed working definition of "terrorist offence," which stipulates that "the instigators of terrorist violence can be an individual, a group, or a government." ${ }^{4}$

The crucial difference between Chadwick and the primarily Western "experts" and defenders of "terrorism" discourse, whom Chomsky and Falk sharply rebuke, ${ }^{55}$ is that Chadwick focuses squarely on the need for an international strategy that accounts for and accommodates the legal rights and entitlements of "peoples" engaged in wars of national liberation. ${ }^{56}$ Chadwick, in common with a broad range of other scholars, argues that the guidance of international humanitarian law is critical in any assessment of "terrorism," and ultimately in any effort to deter its occurrence..$^{57}$ When acts of "terror" and violence are committed in an armed conflict, international humanitarian law furnishes the rules of conduct for both state and non-state actors and distinguishes between permissible and impermissible uses of force ${ }^{58}$ While critical theorists continue to interrogate the broader project of international law and its colonial antecedents, there is much less controversy about the pragmatic utility of using universal rules to define the categories of permissible participants and strategies involved in armed conflict. As noted by Greenwood, even before 1899, "the requirement that certain humanitarian principles be observed in warfare was well established in all main cultures." 59 According to norms that many scholars assert have achieved the status of customary international law, groups that can be identified as a "people" are entitled to use armed force to assert claims of selfdetermination against a state that engages in systematic repression and human rights violations. In such conditions 
an otherwise internal or civil conflict is "internationalized." ${ }^{60}$ Falk indicates that "there is no right to resort to force so long as a government behaves democratically and in fundamental accordance with the basic principles of human rights. But, where a government is oppressive toward a racial or political, ethnic minority or religious minority, or to a constituent people within its sovereignty ... there is an increasing international recognition of the right to armed resistance." ${ }^{11}$ In effect, this is an extension of the principle of self-defence that legitimized the use of force by states against non-state actors, subject to the underlying causes of the conflict. ${ }^{62}$

In Canada, the Geneva Conventions Act directly implements our treaty commitments, ${ }^{{ }^{6}}$ and the government has been an advocate of the principles of equal rights and selfdetermination of peoples at the United Nations. ${ }^{64}$ Acts of violence, no matter how deserving the ultimate goal, underscore the philosophical conundrum of means versus ends and whether it can ever be ethical to sanction death and destruction in support of a just cause. It is difficult, if not deeply problematic from a moral perspective, to justify the deliberate killing of an unarmed population, regardless of the cause or purpose. In this regard, international humanitarian law does not seek to justify or rationalize violence, but rather to assert a comprehensive set of rules that apply to all actors in a conflict-and to promote the prosecution of those who violate the rules clearly and consistently. Thus a claim to "combatant status" does not immunize all acts of violence, but it has a significant impact on the characterization of particular actors and offences. In the context of wars of liberation or independence being waged by groups with a recognized right to selfdetermination, the use of force against military targets or police units empowered to conduct "public order" missions is permitted. When civilians are targeted in attacks by such groups, those acts are subject to sanction as violations of humanitarian law, with recourse to a set of well-established defences. Thus illicit acts of war perpetrated by or on behalf of "peoples" struggling for their rights to self-determination, are a separable phenomenon distinct from individual, sporadic acts of violence in peacetime. As Cassese points out in his study of the Achille Lauro hijacking, "the activities of national liberation movements per se cannot be equated with terrorism ... just because these movements are comprised of irregular combatants fighting against governments, this does not mean they should be seen by the international community as criminal organizations." ${ }^{65}$ In cases where illicit acts are systematic and widespread, Cassese suggests that a state may legitimately consider the armed nucleus or faction of a movement as a criminal or- ganization. However, “. .. such an ... assessment does not necessarily involve the whole movement, so long as the latter pursues legitimate political objectives ..." ${ }^{\prime 66} \mathrm{An}$ in-depth exegesis on international humanitarian law is beyond the scope of this paper, but it should be clear from the foregoing summary that in assessing the means or method of violence employed by states and non-state actors alike, an understanding of the context is essential. Certain acts that are impermissible in peacetime are permitted in war.

Article 21 of the new treaty on the financing of "terrorism" explicitly acknowledges the interplay between its own mandate and international humanitarian law: "Nothing in this Convention shall affect other rights, obligations and responsibilities of States and individuals under international law, in particular the purposes of the Charter of the United Nations, international humanitarian law and other relevant conventions." ${ }^{67}$ Thus full compliance with the treaty would explicitly require its provisions to be interpreted in light of international humanitarian law. Shortly before the treaty opened for signature in January 2000, Canada indicated its intention to sign and ratify it. ${ }^{68}$ The treaty is especially relevant to the Canadian context, because a majority of the refugees and other non-citizens considered security risks under the Immigration Act are not people who have ever engaged in violent activity themselves, but are associated with Canadian organizations that CsIs has identified as "fronts" for fundraising in support of "homeland conflicts." ${ }^{69}$ Before ratifying the treaty, the government will need to review whether existing Criminal Code offences address the requirements of the Treaty, for it imposes an obligation on states to establish as criminal offences the specific offences enumerated in the other terrorist conventions,$^{70}$ as well as,

Any other act intended to cause death or serious bodily injury to a civilian, or to any other person not taking an active part in the hostilities in a situation of armed conflict, when the purpose of such act, by its nature or context, is to intimidate a population, or to compel a government or an international organization to do or to abstain from doing any act. ${ }^{11}$

Arguably domestic law concerning conspiracy, common intention, and aiding or abetting unlawful acts already addresses the situation of people who contribute material support to the commission of illegal acts. While any individual in Canada could be subject to criminal prosecution on these grounds, in practice, prosecutions are never initiated against refugees whom the government finds to be engaged in financing "terrorism." The fact that these refugees have not engaged in any unlawful activities (either in Canada or their country of origin) must be at least a par- 
tial explanation for the absence of such prosecutions. ${ }^{72}$ It should be noted that the un treaty itself criminalizes "terrorist" fundraising only to the extent that funds are collected "wilfully ... with the intention that they should be used or in the knowledge that they are to be used, in full or in part, in order to carry out ..." the specified offences or acts. ${ }^{73}$ Additional provisions indicate that it is also an offence to participate as an accomplice, organize or direct others to commit an offence, or intentionally "contribute to the commission of an offence by a group of persons acting with a common purpose." 74 The Treaty is a clear affirmation that those who financially contribute to violent acts are to be considered just as culpable as those who detonate the bombs.

However, the Treaty's provisions clearly articulate the legal requirement of mens rea. Individuals will be found complicit in the commission of an offence only when they knew or ought to have known that their activities were supporting the crime. The requirement of this mental element is consistent with the standards widely applied in both criminal and refugee law $^{75}$ and necessarily implies that mere membership or affiliation with groups responsible for international crimes would not be sufficient to establish an offence under the treaty.

It is also important to note that the treaty incorporates an express limitation on the duty to extradited offenders who will be subjected to discriminatory applications of the criminal law authority:

Nothing in this Convention shall be interpreted as imposing an obligation to extradite ... if the requested State Party has substantial grounds for believing that the request for extradition ... has been made for the purpose of prosecuting or punishing a person on account of that person's race, religion, nationality, ethnic origin or political opinion or that compliance with the request would cause prejudice to that person's position for any of these reasons. ${ }^{76}$

As Hathaway emphasizes, an individual does not face genuine criminal prosecution where discrimination results in selective prosecution, denial of procedural or adjucative fairness, or differential punishment. ${ }^{77}$

The Treaty further stipulates that its measures must be implemented through the mechanism of domestic criminal law. In the Canadian context, the necessary result would be that anyone alleged to have been involved in financing "terrorism" will be afforded all the safeguards of the criminal justice system, including constitutionally protected rights to counsel, to know and meet and the state's case, and most importantly, the benefit of the criminal law standard of proof-not to be convicted unless guilt is established beyond a reasonable doubt. From a human rights perspec- tive, it would be a significant advance if the Canadian government proceeded to implement the Convention and prosecute alleged offenders. Such action would be viewed as positive, however, only if the government resorted to the criminal law for citizens and non-citizens alike-repudiating the current practice of invoking security certificate and deportation proceedings (with none of the safeguards already mentioned) for refugees and other non-citizens. In the meantime, deportation continues to be the preferred recourse for addressing alleged refugee "terrorists," and so a more thorough examination of the applicable immigration laws and their historical evolution follows.

\section{Canadian Immigration Law and National Security}

Canada's historical record clearly reflects the extent to which each new influx of immigrants engendered reactions that sought to criminalize foreigners and thwart others from gaining admission in the first place. As Stasiulus and YuvalDavis observe, immigration laws have been used in settler societies to encourage "desirable" immigrants to settle in the country and to exclude "undesirable" ones. ${ }^{78}$ In this regard, post-Confederation immigration law and policy in Canada share a trajectory with other colonial states. While seeking to promote immigration as an strategy essential for industrial growth, the newly formed Confederation was equally concerned about controlling entry and safeguarding the developing nation from individuals thought undesirable because of their "race" or nationality, as well as for economic, medical, criminal, or security reasons. Canada's first Act Respecting Immigration and Immigrants, passed in 1869 , was designed primarily to ensure the safety and protection of British immigrants travelling to Canada. As early as 1872 , there was a prohibition against immigrants who might be a security risk. That year an amendment to the Immigration Act provided that "The Governor in Council may, by proclamation, whenever he deems it necessary, prohibit the landing in Canada of any criminal, or other vicious class of immigrants, to be designated by such proclamation." ${ }^{79}$ Section 41 of the Immigration Act of 1910 added to the prohibited classes "any person other than a Canadian citizen [who] advocates in Canada the overthrow by force or violence of the Government of Great Britain or Canada, or other British Dominion, Colony, possession or dependency, or the overthrow by force or violence of constitutional law or authority." ${ }^{\circ 0}$ A privative clause in the Immigration Act denied the right of appeal to anyone who was refused admission or ordered deported pursuant to the Act. ${ }^{81}$

In the wake of the Russian Revolution in 1917, the "Red Scare" in the West, as well as increasing labour unrest in Canada, the scope of Section 41 was widened to include 
anyone who "advocates or teaches the unlawful destruction of property" and anyone who "is a member of or affiliated with any organization entertaining or teaching the disbelief in organized government." The government used this statutory authority to bar entry or deport hundreds of "anarchists and revolutionaries," who were primarily suspected communists and union organizers. ${ }^{82}$ This amendment gave the government the right to deport anyone who was deemed a member of one the inadmissible classes, for up to five years after arrival in Canada. By 1923 all immigrants were required to have visas, and procedures for the examination of visa applicants began to develop. During the inter-war period as well as World War II, the Immigration Act continued to provide government officers with broad discretionary powers to exclude individuals, including "enemy aliens," on the grounds of national security.

Following World War II, the Canadian government sought to expand the immigration program in an effort to meet labour market demands as well as to contribute to the relief of displaced persons in Europe. In recognition of the security problem posed by the surge in immigration, the RCMP was dispatched to London to join the immigration vetting team. In the immediate post-war period, fear of Soviet infiltration (not Nazi collaborators) was the primary security concern. This concern became heightened when a clerk from the Soviet Embassy named Gouzenko defected and revealed the existence of a communist spy network. The "Gouzenko affair" generated a widespread preoccupation within government about security-a concern that grew as Cold War tensions increased. Immigration regulations continued the absolute prohibition on admission of communists, while Cabinet directives authorized a selective course of immigration security screening without deciding whom to screen, how to screen, or what screening criteria would be applied. These decisions were left to the discretion of the RCMP. Records indicate that Cabinet regarded security matters as a key priority but did not want the security process made public. As reported in a recent Federal Court decision, "[n]ot only was the actual process secret but the fact that such a process was in place was a closely guarded secret." ${ }^{{ }_{3}}$

In 1952 a new Immigration Act was implemented, governing Canadian immigration procedures for the following twenty-five years. Section 5 of the Act listed the classes of persons who were prohibited from admission to Canada, while Section 19 provided the authority to deport those already in Canada on security grounds. ${ }^{84}$ According to the Act, individuals were considered security risks who are, have been, or are likely to become "members of or associated with any organization, group or body of any kind concern- ing which there are reasonable grounds for believing that it promotes or advocates ... subversion by force or other means." ${ }^{185}$ Other subsections of the Act specifically addressed related security risks, including espionage, sabotage, and treason. The Immigration Appeal Board Act of 1967 implemented a right of appeal for people facing deportation but also set out the conditions for overriding appeal procedures in serious security cases. ${ }^{86}$ From its early roots through to the 1960 s, the explicit objective of immigration law and policy was to sustain the British character of Canada and exclude those who were thought incapable of contributing to the government's assimilationist project of nation building. The driving force behind measures of national security and immigration control during this period was the Anglo-Saxon fear that the influx of foreigners threatened the nation's "racial purity" and/or political fabric. ${ }^{87}$

Canada became a party to the 1951 United Nations Convention on the Status of Refugees (Refugee Convention) in 1969. The Convention carved out an explicit exception to the notion that states had the absolute prerogative to decide whom to admit to their territories. ${ }^{88}$ Qualified refugees would no longer be seeking a privilege, but be asserting a right that statutory states would be obliged to consider. Despite the idealism and neutral language embedded in the Convention, ideological considerations frequently informed Canada's response to international refugee crises, particularly in the early years of the Cold War. The refuge provided to people fleeing communist regimes in Hungary in 1956, Czechoslovakia in 1968, and Vietnam in 1979, while the relatively closed door offered to Chilean refugees fleeing Pinochet's coup in 1973, are striking manifestations of this tendency. ${ }^{89}$

In response to a government green paper recommending that immigration legislation should embody a more positive approach, a new Immigration Act was implemented in 1978.90 This legislation, amended several times over the past twenty-two years, is still in force. For the first time, the objectives of Canada's immigration policy were explicitly spelled out. These included attainment of Canada's demographic goals, promotion of family reunification, and development of a strong economy. The Act included among its purposes the imposition of standards of admission that do not discriminate on grounds of race, national, or ethnic origin, colour, religion, or sex; the fulfilment of Canada's international legal obligations to refugees and upholding its humanitarian tradition towards the displaced and the persecuted; the maintenance and protection of the health, safety, and good order of Canadian society, and promotion of international order and justice by denying the use of Canadian territory to persons who are likely to en- 
gage in criminal activity. ${ }^{91}$ The Act incorporated the essential parts of the 1951 Convention definition of a refugee and its "exclusion clauses." Protection would be afforded to persons with a well-founded fear of persecution for reasons of race, religion, nationality, or membership in a particular social group or political opinion. Status would be denied to those not deserving protection, including the perpetrators of war crimes, serious non-political crimes, and acts "contrary to the purposes and principles of the United Nations." The Act also incorporated the principle of nonrefoulement, the positive commitment not to remove refugees to a country where their life or freedom would be threatened for any of the Convention reasons. Exceptions, consistent with the Refugee Convention, were stipulated for persons who constituted a danger to "the security of Canada” or public safety.92 In 1977 United Nations High Commissioner for Refugees (UNHCR) had cautioned that as exceptions to an important protection principle, the security and public order provisions should be interpreted and implemented restrictively. ${ }^{93}$ Neither the Act nor subsequent regulations referred to the meaning of "security of Canada" 94 or the UNHCR's caution.

Section 19 (1) of the Act established a somewhat refined list of classes of people who were inadmissible to Canada for security reasons: persons who there are "reasonable grounds to believe" have engaged or will engage in espionage, subversion against democratic government, and subversion by force of any government. ${ }^{95}$ In addition, persons were inadmissible where "there are reasonable grounds to believe [they] will engage in acts of violence that would or might endanger the lives or safety of persons in Canada or are members of or likely to participate in the unlawful activities of an organization that is likely to engage in such acts of violence." ${ }^{96}$ Finally, there was a provision to exclude persons who had committed war crimes and crimes against humanity. ${ }^{97}$ The Act explicitly referred to the Criminal Code for the purposes of defining war crimes and crimes against humanity, and the Code's definitions of "public order offences" would clearly be relevant to the interpretation of espionage. However, nothing in the new Act, regulations, or administrative policy provided any criteria or guidance for what constituted "membership" or "subversion." Over the next decade, Canada opened its doors to thousands of refugees from non-traditional source countries. However, Canada's record of compliance with international human rights standards and the Refugee Convention in particular continued to be uneven. ${ }^{98}$

In the wake of concerns about the conduct of the Security Service of the RCMP in the 1970s, the government established the Commission of Inquiry Concerning Certain
Activities of the RCMP commonly referred to by the name of its chair, Mr. Justice D.C. McDonald. In 1981 the McDonald Commission released its second report, Freedom and Security under the Law. ${ }^{99}$ The Commission found that the RCMP had subjected many groups, including the "new left," Quebec separatists, unions, the Indian movement, and others to surveillance, infiltration, and "dirty tricks," solely on the grounds that they were exercising their freedom of expression through lawful advocacy, protest, and dissent. A full chapter of the Commission's report addressed immigration security screening. The Commission found that the statutory security criteria set out in the Immigration Act were "too broad" and were inconsistent with the definition of "threats to the security of Canada," which the Commission proposed should inform all security-related screening activities. ${ }^{110}$ The Commission observed,

Canada must meet both the requirements of security and the requirements of democracy: we must never forget that the fundamental purpose of the former is to secure the latter... In taking the position that the requirements of security in Canada must be reconciled with the requirements of democracy, let us be clear that we regard responsible government, the rule of law and the right to dissent as among the essential requirements of our system of democracy. ${ }^{101}$

Although the Commission recommended including political violence and "terrorism" within the admissibility provisions of the Immigration Act, it underscored the importance of distinguishing between international groups secretly pursuing in Canada their terrorist objectives against foreign governments, from representatives of foreign liberation or dissident groups who come to Canada to promote their cause openly. ${ }^{102}$ Based on the Commission's findings, Parliament endorsed the establishment of a new security intelligence agency, outside of the RCMP, with a mandate to investigate and advise but without prosecutorial or enforcement powers. In 1984 the Canadian Security Intelligence Service Act was adopted, and the service was created to, among other things, provide government departments and agencies with security assessments on prospective immigrants. Section 2 of the csis Act defines "threats to the security of Canada" as being (1) espionage or sabotage; (2) foreign-influenced activities within or in relation to Canada that are detrimental to its interests and are clandestine or deceptive and involve a threat to any person; (3) activities within or relating to Canada, directed toward or in support of the threat or use of serious violence against persons or property for the purpose of achieving a political objective within Canada or a foreign state; and (4) activities directed against undermining by covert unlawful acts—or directed toward or intended ultimately to lead to 
the destruction or overthrow by violence of - the constitutionally established system of government in Canada. The statutory language in Section 2 is very broad and has been the subject of criticism for this reason. As Gorlick notes, statutory terms such as clandestine or deceptive and foreign influenced are not defined in the Act, and "inevitably the interpretation of such terms will fall to the agency that has the most to gain from statutory power, that is, CSIs itself." ${ }^{103}$ An important safeguard, however, is the inclusion at the end of Section 2 of the specific qualification that a threat to the security of Canada "does not include lawful advocacy, protest or dissent unless carried in conjunction with any of the activities referred to above." ${ }^{104}$

Parliament failed to implement the McDonald Commission's proposals on revising the Immigration Act. The result is that the definition used by csis officers to investigate and provide advice to ministers on security risks that may be posed by prospective immigrants continues to be inconsistent with the admissibility provisions of the Immigration Act. Whereas the term threat in the csis Act is specifically defined in terms of enumerated activities rather than associations, the Immigration Act maintained its use of broad admissibility categories. Over the next decade many of the criticisms surfaced that had been levelled against the RCMP, and now were directed at the new security intelligence agency and the practices and conduct of its officers. ${ }^{105}$ Complaints have been made to the Security Intelligence Review Committee (SIRC), the agency "watchdog" for csis, documenting the extent to which the service has crossed the line and is engaging not just in monitoring threats to the security of Canada, but, like the RCMP before when dealing with "subversives," is intruding into the lives and futures of those involved in legitimate forms of expression and dissent. ${ }^{106}$ Reporting on investigations spanning several years, sIRC found instances in which csis instructions that sources report on only "authorized subjects of an investigation" had not been fully implemented. ${ }^{107}$ Also noted was "an occasional lack of rigour in the Service's application of existing policies, which oblige it to weigh the requirement to protect civil liberties against the need to investigate potential threats." ${ }^{108}$ Media reports have exposed how, in some cases, refugees have been overtly or implicitly induced to become informers on fellow community members - with promises of prompt resolution of their own residence applications. ${ }^{109}$ All prospective immigrants, including refugees, are under a certain compulsion to cooperate with csis officers, as a positive recommendation from the Service is a condition for obtaining permanent residence status and citizenship.

Canada signed the 1984 Convention Against Torture
$(\mathrm{CAT})$ in 1985 without any reservation and ratified it in 1987 , after extensive consultations with provincial and territorial governments. ${ }^{110}$ Article 3 of the CAT imposes an absolute, non-derogable obligation on states not to return anyone to a country where she or he is at risk of torture, effectively superseding the security exception in the Refugee Convention. ${ }^{111}$ Although the government was an increasingly vocal proponent of human rights standards and institutions in international and regional fora, no steps were taken to incorporate the obligations assumed under Article 3 of the CAT into domestic immigration law. ${ }^{112}$ In the same period, the government was setting up the Immigration and Refugee Board that would provide refugee claimants with an oral hearing. A Supreme Court decision interpreting the new Charter of Rights and Freedoms held that existing administrative procedures for determining refugee status inside Canada failed to meet the procedural guarantees of fundamental justice. ${ }^{113}$

In 1992, as Cold-War security considerations had given way to an increasing preoccupation with deterring "illegal migration" from the South, the Canadian government introduced a series of restrictive amendments to the Immigration Act. Bill c-86 made changes to the overall structure of existing immigration security procedures and enumerated a set of specific objectives for the scheme under the heading "Safety and Security of Canada." Section 38.1 of the amended Act articulated the purposes of the security procedures:

Recognizing that persons who are not Canadian citizens or permanent residents have no right to come into or remain in Canada and that permanent residents have only a qualified right to do so, and recognizing the necessity of cooperation with foreign governments and agencies in maintaining national security, the purposes of sections 39 to 40.2 are

(a) to enable the Government of Canada to fulfil its duty to remove persons who constitute a threat to the security or interests of Canada or whose presence endangers the lives or safety of persons in Canada;

(b) to ensure the protection of sensitive security and criminal intelligence information; and

(c) to provide a process for the expeditious removal of persons found to be members of an inadmissible class referred to in section 39 or $40.1 .^{114}$

Bill c-86 introduced a new form of criminality into the Act, provisions to render refugees and immigrants "inadmissible" where there are reasonable grounds to believe they will "engage in terrorism" 115 or are "members of an organization that there are reasonable grounds to believe will ... engage in terrorism." ${ }^{116}$ An additional subsection provided that persons are inadmissible if they have engaged in "ter- 
rorism," or are "members of an organization that was engaged in terrorism," unless they can satisfy the Minister that their admission would not be detrimental to the national interest. ${ }^{117}$ According to former Solicitor General Doug Lewis, these clauses were designed to ensure that Canada does not become a safe haven for retired or active terrorists. ${ }^{118}$ The subsections dealing with espionage and subversion were broadened to include within their ambit past or present membership in organizations that have engaged in these acts in the past, are engaging in them now, or will engage in them in the future. ${ }^{119}$ The package of amendments also introduced "access criteria" into the Act, requiring all refugee claimants to undergo an eligibility determination pursuant to an enumerated list of disqualifications that were based, among other things, on the new security admissibility criteria. In cases where the Minister found it "contrary to the public interest," claimants would be divested of the right to pursue their refugee claim. ${ }^{120}$ Subject to a further ministerial opinion that they constituted a "danger to the security of Canada," Convention refugees as well as those deemed ineligible to claim refugee status were to be deported back to the very countries from which they fled and where their lives or freedom would be threatened. ${ }^{121}$ In defence of the legislative amendments, it was suggested that the former Immigration Act "put the safety and security of Canadians at risk ... [and] we have to face the fact that the world of the 1990's is a world of increasingly sophisticated, internationally organized criminals and terrorists."122

Once the amendments contained in Bill c-86 were implemented, immigration officers had an expanded basis to support determinations of inadmissibility. With the new provisions on "terrorism," the Immigration Act delegated the job of identifying possible terrorists to csis while retaining for its own department the ultimate authority to decide who will be excluded from Canada on the basis of possible links to "terrorism." Certain refugee communities found themselves increasingly subject to surveillance by csis. Long delays associated with security clearance procedures meant that some individuals could expect to wait years before being able to sponsor family members, enrol in post-secondary education, start a business, or travel outside the country. Complaints lodged with SIRC about these delays or the nature of advice provided by the Service failed to resolve the problems. In three recent Kurdish cases, SIRC Chairman Robert Rae concluded that adverse assessments provided by csis were based on inaccurate assumptions. Despite the extensive investigations and hearings that supported SIRC's conclusions in these cases, the Service responded by preparing "updated assessments" in defence of its original advice, a move that has been interpreted as an attempt to overrule and effectively discredit the committee. ${ }^{123}$ The absence of definition or discriminate content for the terms terrorism, membership in a terrorist organization and security of Canada, permits the Minister of Citizenship and Immigration unfettered discretion to issue security certificates. Unlike the procedures set up in the United Kingdom, where there are statutory definitions and the designation by the executive of which groups and organizations meet the definition, is subject to approval by both Houses of Parliament and even appeal, ${ }^{124}$ there are no public procedures to deal with the designation of terrorist organizations.

By the 1990s there was an emerging consensus among scholars and legal experts that both the principle of nonrefoulement and the prohibition against torture had become rules of customary international law, and further, peremptory norms of jus cogens. ${ }^{125}$ In the extradition context, two Supreme Court rulings confirmed that fundamental justice should prevent Canada from surrendering a fugitive to a foreign state in circumstances where they would be subjected to torture. ${ }^{126}$ In the same spirit, in 1996 Canadian government representatives in Geneva joined in the consensus for the 1996 Conclusion of the UNHCR's Executive Committee in reaffirming "the fundamental principle of non-refoulement, which prohibits the expulsion and return of persons in respect of whom there are grounds for believing that they would be in danger of being subjected to torture, as set forth in the Convention against Torture."127 Yet within the next two years the government executed deportation orders in direct contravention of requests by the United Nations Committee against Torture and the InterAmerican Commission on Human Rights. ${ }^{128}$ Domestically, the government was maintaining its firm commitment to its "right" to deport criminals ${ }^{129}$ and "security risks," regardless of the human rights at issue. ${ }^{130}$ Although a United Nations resolution urges states to ensure that refugee status is "not used for the purpose of preparing or organizing terrorist acts," ${ }^{131}$ international institutions firmly support an absolute prohibition against deporting anyone to a county where there is risk of torture. ${ }^{132}$ Removal is also proscribed to a country where fair trial guarantees are absent, the death penalty will be imposed (albeit with considerable variation in state practice in this regard $)^{133}$ or, with some balancing of interests, in cases that result in statelessness, ${ }^{134}$ and family separation, particularly where children are involved. ${ }^{135}$

Meanwhile, over the past several years, there have been repeated calls from some quarters for Canada to restrict access to its refugee program and an increasing public perception that Canada's "porous" borders are endangering 
Canadians. ${ }^{136}$ In response to such concerns, the federal government commissioned a series of studies and consultations, ${ }^{137}$ and most recently proposed a number of wideranging reforms to the Immigration Act. Although Bill c31, the Immigration and Refugee Protection Act, will not be implemented because of the recent federal election, it provides a good indication of future policy directions. As for national security issues, the bill maintained the provisions related to "membership" and "terrorism," with no definition or statutory criteria for either term. There was provision for discretionary relief in circumstances where the minister was "satisfied that the admission would not be detrimental to the national interest." ${ }^{13^{8}}$ The bill failed to address repeated recommendations that the definition of security threat in the Act be harmonized with the definition in the csis Act. ${ }^{139}$ In addition to proposing broader grounds for security inadmissibility, the bill proposed to treat permanent residents and other non-citizens in the same manner under a new category as "foreign nationals." Currently, permanent residents faced with security proceedings have automatic access to SIRC, which examines the basis of the security opinion and provides an important check on the authority of csis. SIRC counsel have an opportunity to question witnesses who have been permitted to testify ex parte and in effect represent the interests of the person concerned. A summary of such evidence, subject to security "expurgation," is provided. It is only after the hearing is completed that SIRC issues a recommendation to the Governor in Council on whether a certificate should be issued. ${ }^{140}$ In proceedings involving non-permanent residents, on the other hand, the certificate has already been issued and the task of a "designated judge" (one of a small number of Federal Court judges who have received special clearance to review security cases) is to determine whether it should be quashed. The government's case is presented primarily in secret and in the absence of the person concerned. In most cases, the csis officers who actually conducted the interviews and tendered the adverse security recommendation are not made available for questioning. The court has no independent counsel to assist, nor are there any special rules governing the unique features of such hearings. ${ }^{141}$ Bill c-31 proposed the lower standard of procedural justice for all foreign nationals by stripping sIRC of its current responsibility for permanent residents. Both refugees and permanent residents were to be accorded only an "informal and expeditious" Federal Court review of ministerial security opinions, with no possibility of further review or appeal. It deserves mention that ten years ago, a parliamentary review of the csis Act recommended that the Immigration Act be amended to allow any person subject to an adverse security report to have the case investigated by SIRC, with direct recourse to an administrative hearing. ${ }^{142}$ The latest legislative initiative not only failed to address the existing shortcoming in the Act, but was proposing to further erode an essential safeguard. Although the bill contained new references to the CAT, the explicit exemption authorizing the Minister to deport people regardless of the risks they might face, remained in place for designated security cases. ${ }^{143}$

The overhaul of the Immigration Act in 1978, implementation in 1982 of the Canadian Charter of Rights and Freedoms, as well as the emergence of new international standards, generated considerable optimism about the prospects for a meaningful amelioration of conditions for immigrants and refugees as historically disadvantaged groups in Canadian society. Recourse to "Charter challenges" would offer an important mechanism of accountability, with the courts providing aggrieved individuals direct access to public decisions affecting their lives and an opportunity to challenge laws independent of government law reform agendas. ${ }^{14}$ Despite these lofty hopes, the foregoing review of the national security/admissibility provisions in Canadian immigration law discloses little evidence of progress. The individuals and groups subject to security targeting may have changed, but the measures proposed in 2000 bear remarkable similarity to historical forms of exclusion. The enforcement of the seemingly neutral admissibility provisions and their attendant procedures leave wide scope for unprincipled and discriminatory decision with virtually no appeal mechanism and limited procedural rights. Resort to the courts has not addressed the inequities in the system but instead has frequently reinforced them.

The second part of this paper will include a closer look at Federal Court jurisprudence concerning refugees and other non-citizens alleged to be "terrorists" or members of "terrorist" organizations.

\section{Endnotes}

1. J. Zulaika and W. Douglas, Terror and Taboo (New York: Routledge, 1996) at x, xi, 16.

2. O. Elagab, International Law Documents Relating to Terrorism, 2nd ed. (London: Cavendish Publishing Limited, 1997) at xx.

3. The words terrorism and terrorist are placed within quotation marks throughout this paper in recognition of their meaninglessness as a legal category.

4. T.H. Mitchell, "Defining the Problem" in D.A. Charters, ed., Democratic Responses to International Terrorism (New York: Transnational Publishers, 1991) at 10.

5. Ibid., at 11 .

6. CSIS, “Trends in Terrorism,” Report \#2000/01, 18 Dec. 1999 $<$ www.csis.gc.ca/eng/miscdocs/200001e.html > at 2; and Report 
of the Special Senate Committee on Security and Intelligence (Kelly Committee), January 1999 <www.parl.gc.ca/36/1/parlbus/ commb.../com-e/secu-e/rep-e/repsecintjan99-ehtm > c.1 at 2.

7. Kelly Committee, ibid., c.1 at 14 .

8. B. Gorlick, "The Exclusion of 'Security Risks' as a Form of Immigration Control: Law and Process in Canada” (1991) 5:3 Immigration and Nationality Law and Practice 76.

9. See P. Shah, "Taking the 'Political' out of Asylum: The Legal Containment of Refugees' Political Activism" in F. Nicholson and P. Twomey, eds., Refugee Rights and Realities (Cambridge: Cambridge University Press, 1999) 119-135.

10. R. Whitaker, "Refugees: The Security Dimension" (1998) 2:3 Citizenship Studies 413 at 427.

11. Ibid.

12. Ibid. at 430 .

13. Institutional racism can manifest in the form of explicitly racist policies in which the state directly reinforces racist biases in society, or it can be found in systemic form ("systemic racism") concealed in systems, practices, policies, and laws that appear neutral and universalistic, but disadvantage racialized persons. The Commission on Systemic Racism in the Ontario Criminal Justice System noted that racism has "a long history in Canada." While the focus of the provincial study was the criminal justice system, the commissioners emphasized that " $[\mathrm{r}]$ acism has shaped immigration to this country and settlement within it..." An examination of Canadian immigration law and policy from historical and contemporary perspectives requires an analysis of racism as a defining feature of Canadian society. Report of the Commission on Systemic Racism in the Criminal Justice System (Ontario: Queen's Printer, 1995); Stephen Lewis Report on Race Relations in Ontario (Ontario: Queen's Printer, 1992).

14. In a meeting between representatives of the Canadian Council for Refugees (CCR) and the Senior Director for Security Review with the Department of Citizenship and Immigration (CIC), cIC acknowledged that some Kosovars had joined the KLA because it was "the only way to protect themselves and their families;" and that in such circumstances the individuals were not declared inadmissible. (Montreal,12 September 2000).

15. Canadian Council for Refugees, Report on Systemic Racism and Discrimination in Canadian Refugee and Immigration Policies, in preparation for the un World Conference on Racism, Racial Discrimination, Xenophobia and Related Intolerance, 1 Nov. $2000<$ www.web.net/ ccr/antiracrep.htm>.

16. H. Bannerji, The Dark Side of the Nation (Toronto: Canadian Scholars' Press, 2000) at 115. See also, D. Matas, "Racism in Canadian Immigration Policy" in C. James, ed., Perspectives on Racism and the Human Services Sector (Toronto: University of Toronto Press, 1996); L. Jakubowski, "Managing Canadian Immigration: Racism, Ethnic Selectivity, and the Law" in E. Comack et al., Locating Law, Race/Class/Gender Connections (Halifax: Fernwood Publishing, 1999 ); A. Simmons, "Racism and Immigration Policy" in V. Satzewitch, ed., Racism and Social Equality in Canada (Toronto: Thompson Educational Publishing, 1998).

27. For an excellent account of one such interview/interrogation experienced by Suleyman Goven, a Kurdish refugee from Tur- key, see M.J. Leddy, At the Border Called Hope (New York: Harper Collins, 1997) at 76-82; and the recent conclusions of the Security Intelligence Review Committee (SIRC), discussed infra, In the Matter of the Complaints under the Canadian Security Intelligence Service Act by S.G. and S.D., SIRC File Nos. 1500-82, 83,7 April, 2000, in which the Committee upheld two complaints, recommending in particular the need for Canadian Security Intelligence Service (csis) officials making assessments to develop a more sophisticated analytic framework, the entitlement of the applicant to written notice of the date and time of the interview, its purpose, and the fact that the applicant has the right to attend with counsel (at 31). Mr. Goven's complaint was one of three immigration security screening complaints on which SIRC rendered decisions in 200o. In the wake of sIRC's findings in these three cases, a new policy has been adopted that will provide applicants two to eight weeks' written notice of the interview by a convocation letter specifying that the interview will be with a csis employee. See SIRC Annual Report, 1999-2000 at 82, footnote, 33 <www.sirc-csara.gc.ca/annual/19992000/ar9900_e.html>.

18. In the past year Csis conducted 81,650 immigration security screening assessments, of which 109 contained notification that the individual "is or was" a member of an inadmissible class as defined in s. 19(1) of the Immigration Act. SIRC Annual Report 1999-200o, ibid., at 36 . The number of individuals subsequently subject to security certificate procedures or left in legal limbo due to inaction on the part of CIC is not published. However, a CIC official recently indicated that there are approximately 250 security cases pending with the department, of which 150 , or 60 per cent, are Convention refugees within Canada, a further 20 per cent are overseas applicants, and 20 per cent are nonrefugee cases. Supra note 10.

19. J.J. Paust et al., "Terrorism" in International Criminal Law: Cases and Materials, 2nd ed. (Durham, N.C.: Carolina Academic Press, 2000) at 999-1000.

20. See P. St. John, "Counterterrorism Policy Making: The Case of Aircraft Hijacking, 1968-1988” in D.A. Charters, ed., supra note 4 at $73-77$.

21. N.J. Schrijver, "Interpreting the Principles and Purposes of the United Nations" in P.J. van Krieken, ed., Refugee Law in Context: The Exclusion Clause (The Hague: T.M.C. Asser Press, 1999) 237 at 244. See also, Reference Re Secession of Québec [1998] 2 S.C.R. 217.

22. Ibid.

23. R. Higgins, "The General International Law of Terrorism" in R. Higgins and M. Flory, eds., Terrorism and International Law (London: Routledge, 1997) at 16.

24. Mitchell, supra note 4 at 14 . Several years later, members of the Ad Hoc Committee on International Terrorism drew attention "to the unacceptability of a broad interpretation of the concept of international terrorism which would include the national liberation struggle, acts of resistance against the aggressor in territories occupied by the latter and demonstrations by workers who were opposed to exploitation." Report of the Ad Hoc Committee on International Terrorism, ch. 2, Summary of the General Debate, UN Doc. A/34/37 (1979), para. 16; and see paras. 
30-31.

25. U.N.G.A. Res. 53/108, 26 Jan. 1999 at para. 1. See U.N.G.A. Res. 3034, 18 Dec. 1972; UN G.A. Res. 44/29, 6 Dec. 1989; U.N.G.A. Res. 46/51, 9 Dec. 1991, UN Doc. A/46/54; and the Declaration on Measures to Eliminate International Terrorism, annex to UN G.A. Res. 49/60, 9 Dec. 1994, which states, inter alia, that "criminal acts intended or calculated to provoke a state of terror in the general public, a group of persons or particular persons for political purposes are in any circumstances unjustifiable, whatever the considerations of political, philosophical, ideological, racial, ethnic, religious or any other nature that may be invoked to justify them." See also Measures to Eliminate International Terrorism, UN G.A. Res. A/51/631, 4 Dec.1996; and UN G.A. Res. A/51/210, 16 Jan. 1997.

26. The eleven Conventions include: the Tokyo Convention on Offenses and Certain Other Acts Committed on Board Aircraft, 1963; the Hague Convention for the Suppression of the Illegal Seizure of Unlawful Acts against the Safety of Civil Aviation, 1970; the Montreal Convention for the Suppression of Unlawful Acts against the Safety of Civil Aviation, 1971; the Protocol to the Montreal Convention for the Suppression of Unlawful Acts of Violence at Airports serving Civil Aviation, 1988; the International Convention on the Prevention and Punishment of Crimes against Internationally Protected Persons, including Diplomatic Agents, 1973; the International Convention against the Taking of Hostages, 1979; the Rome Convention on the Suppression of Unlawful Acts against the Safety of Maritime Navigation, 1988; the Protocol on the Suppression of Unlawful Acts against the Safety of Fixed Platforms Located on the Continental Shelf, 1988; the Montreal Convention on the Marketing of Plastic Explosives for the Purpose of Detection, 1991; the International Convention for the Suppression of Terrorist Bombings, 1998; and the International Convention for the Suppression of the Financing of Terrorism, 1999. Two instruments, while not directed expressly at terrorism, are also relevant: the Convention on the Prohibition on the Development, Production, and Stockpiling of Bacteriological (Biological) and Toxic Weapons and on Their Destruction, 1972; and the Vienna Convention on the Physical Protection of Nuclear Material, 1980.

27. See OAS Convention to Prevent and Punish Acts of Terrorism Taking the Form of Crimes against Persons and Related Extortion that Are Internationally Significant, 1971, which avoids defining terrorism in favour of an enumerated list of "common crimes of international significance" that includes "kidnapping, murder, and other assaults against the life or personal integrity of those persons to whom the State has the duty to give special protection ... as well as extortion in connection with those crimes" (art. 2). Art. 6 indicates that "[n] one of the provisions of this convention shall be interpreted so as to impair the right of asylum." See also, European Convention on the Suppression of Terrorism, 1977; European Communities, Agreement Concerning the Application of the European Convention on the Suppression of Terrorism among Member States, 1979; SAARC Regional Convention on the Suppression of Terrorism, 1987.

28. A draft text proposing that inclusion of "crimes of terrorism" within the parameters of the Court's jurisdiction was not adopted. In addition to listing offences under the major UN terrorism treaties, the text indicated that the Court would have jurisdiction over "Undertaking, organizing, sponsoring, ordering, facilitating, financing, encouraging or tolerating acts of violence against another State [emphasis added] directed at persons or property and of such a nature as to create terror ... for whatever considerations and purposes ..." Preparatory Committee on the Establishment of an International Criminal Court 11-21 Feb. 1997, Working Group on Definition of Crimes, UN Doc. A/AC.249/1997/WG.1/CRP.4 at para.1.

29. One hundred and twenty states voted in favour of the establishment of the ICC, and twenty-two of the sixty states required for the Statute to enter into force have ratified it. Canada signed the Rome Statute in December 1998 and ratified it on 7 July 2000. See $<$ www.un.org/law/icc/statute/status/htm $>$. The Rome Statute is the most current codification of a universal approach to combating serious international crimes. See <www.un.org/ law/icc/statute/romefra.htm>. Within the ambit of "war crimes," defined in Article 8, are wilful killing, torture, taking of hostages, intentionally directing attacks at civilian populations or civilian objects, and attacking or bombarding undefended towns or buildings. The Statute sets a higher threshold for crimes committed in internal wars, stating the Court's jurisdiction extends only to acts that take place in a state where there is a "protracted armed conflict between government authorities and organized armed groups or between such groups."

30. See Rome Statute, art. 25(3) "Individual Criminal Responsibility," art. 28, "Responsibility of Commanders and Other Superiors," and art. 30, "Mental Element"; See also Report of Preparatory Commission for the ICC, Finalized Draft Text of the Elements of Crimes, PCNICC/200o/INF13/Add.2, <www.un.org/ law/icc/statute/elements/english/add2e_w.doc $>$; and the decision of the International Criminal Tribunal for the Former Yugoslavia in Prosecutor v. Tadic, which gave extensive consideration to the question of criminal responsibility, Opinion and Judgment. Case No. IT-94-1-T, 7 May 1997, paras. 688-692.

31. The G8 (Group of 8) countries are Canada, France, Germany, Japan, Italy, Russia, the U.K., and the U.S.A.

32. Measures adopted during the G7/P8 Ministerial Conference on Terrorism, Paris, June 1996, as cited E. Chadwick, “Terrorism and the Law: Historical Contexts, Contemporary Dilemmas, and the End(s) of Democracy" (1997) 26 Crime, Law and Social Change 329 at 330, and SIRC Annual Report 1999-200o, Section 1 n.6.

33. P. Webster and I. Brodie, "G7 Vow to Pursue Terrorists," The Times, 27 June 1996 at 14. Ironically, the United States has refused to sign the 1998 Convention for the Suppression of Terrorist Bombings.

34. Criminal Code, ss. $76,77,78,78.1$. Until this year, s. 7 of the Criminal Code stipulated that in cases where the alleged acts were committed outside Canada, prosecutors had to prove an offence under international law as well as an equivalent offence in the Code. This was one of the reasons that prosecution of World War II war criminals has been difficult, particularly after the Supreme Court's ruling in R. v. Finta [1994] 1 S.C.R. 701.

35. The Crimes against Humanity Act, R.S.C. 2000 c. 24, imple- 
ments Canada's obligations under the Rome Statute. It amends, inter alia, the Criminal Code by replacing the jurisdictional provisions of 5.7 with the actual offences of genocide, crimes against humanity, and war crimes, enhancing the government's capacity to prosecute and punish persons accused of these crimes. This Act closes the technical loophole left in the wake of the Supreme Court's ruling in Finta.

36. In response to what many scholars have described as a "very modest terrorist threat," the Canadian government proclaimed the War Measures Act, which gave the police sweeping powers to arrest and detain anyone suspected of association with the FLQ. The use of these powers was widely criticized at that time and "has come to be regarded as a heavy-handed overreaction." W.M. Vaughn, "Canadian Reason of State: Terrorism, Emergency Powers, and Civil Liberties" in D.A. Charters, ed., supra note 4 at 165 .

37. As discussed in A. Cassese, Terrorism, Politics and Law (Princeton, N.J.: Princeton University Press, 1989) at 121-123.

38. J.J. Paust et al., supra note 19 at 1020.

39. See R. Slater and M. Stohl, "Introduction" in R. Slater and M. Stohl, eds., Current Perspectives in International Terrorism (New York: Macmillan, 1988) at 1-11; A.P. Schmid and R.D. Creliston, Western Responses to Terrorism (London: Frank Cass, 1993) at 11; and P.P. Heymann, Terrorism and America (Cambridge: MIT Press, 1998) at 3-9.

40. A.P. Schmid and A.J. Jongman, Political Terrorism: A New Guide to Actors, Concepts, Data Bases, Theories and Literature (New Brunswick, N.J.: Transaction Books, 1988) at 1-38.

41. J.F. Murphy, "The Need for International Cooperation in Combatting Terrorism” (1990) 13 Terrorism: An Int'l. J. 381, quoting W. Lacqueuer (citation omitted).

42. J. Lambert, "The Problem of International Terrorism and the Response of International Organizations" in P.J. van Krieken, Refugee Law in Context: The Exclusion Clause" (The Hague: T.M.C. Asser Press, 1999) at 177.

43. W. Lacqueur, ed., The Terrorism Reader (1979) at 262, and The Age of Terrorism (1987) at 11, as cited in J. Lambert, "The Problem of International Terrorism and the Response of International Organizations" in P.J. van Krieken, ibid., at 177.

44. G. Levitt, "Is ‘Terrorism’ Worth Defining?” (1986) 13 Ohio N.U.L. Rev. 97.

45. R. Higgins, supra note 23 at 28.

46. J. Borricand, "France's Responses to Terrorism" in R. Higgins and M. Flory, eds., supra note 23 at 145.

47. Ibid.

48. Zulaika and Douglas, supra note 1 at 96-99.

49. N. Chomsky, Necessary Illusions: Thought Control in Democratic Societies (Concord, Ontario: House of Anansi Press Limited, 1991) at 287; and see - The Culture of Terrorism (London: Pluto Press, 1988); - Pirates and Emperors (Montreal: Black Rose Books, 1991). In a similar critique, Said notes that the terms fundamentalism and terrorism " . . . signify moral power and approval for whoever uses them, moral defensiveness and criminalisation for whomever they designate." E. Said, Culture and Imperialism (London: Chatto and Windus, 1993) at 375 .
50. E. Herman and G. O'Sullivan, The Terrorism Industry: The Experts and Institutions that Shape Our View of Terror (New York: Pantheon Books, 1990) at 218-219.

51. R. Falk, Revolutionaries and Functionaries: The Dual Face of Terrorism (New York: E.P. Dutton, 1988) at 164.

52. "Colombo Hails Ban on the LTte," The Hindustan Times, 10 Oct. 1997. A few months later, in January 1998, the Sri Lankan government formally outlawed the LTTE.

53. E. Chadwick, Self-Determination, Terrorism and the International Humanitarian Law of Armed Conflict (The Hague: Martinus Nijhoff Publishers, 1996) at 120.

54. Ibid., at 3 .

55. Wilkinson suggests that "there should be no special privileges or discrimination in favour of those who plead political motives for their crimes of violence. According terrorists special status only serves to legitimise and perpetuate their own selfperception as 'freedom fighters' ..." P. Wilkinson, "The Strategic Implications of Terrorism" in M.L. Sondhi, Terrorism and Political Violence, A Sourcebook (India: India Council of Social Science Research, Har-Anand Publications, 2000); and see Terrorism and the Liberal State, 2nd ed. (London: Macmillan, 1986). For an analysis of the "terrorism industry," its links with Western governments, and the scholarship that sustains it (including the work of Wilkinson), see Herman and O'Sullivan, supra note 50.

56. None of the international instruments that identify the rights inhering in "peoples" actually define the term, thereby providing no guidance on which "peoples" are entitled to self-determination. In the early years of the UN states attempted to restrict the interpretation of the term in the interest of preserving territorial units. Scholars now suggest that the term peoples has evolved to mean groups that share common political goals, a will to live together, and clear ethnic and/or cultural ties. Chadwick, supra note 53 at 4-5.

57. International humanitarian law ( $\mathrm{IHL}$ ) includes two main branches: the law of war, and limited aspects of human rights law. It is principally concerned with jus in bello, that is, the rules applicable during armed conflicts, governing the conduct of hostilities and the protection of persons affected by the conflict. The primary treaty instruments that codify these rules are the four 1949 Geneva Conventions for the Protection of War Victims and the 1977 Protocols I and II Additional to the Geneva Conventions of 1949. The Geneva Conventions are considered customary, as are parts of the 1977 Additional Protocols. International law also addresses jus ad bellum, that is, the rules governing resort to force. See A. McDonald, "Introduction to International Humanitarian Law and the Qualification of Armed Conflicts" in P.J. van Krieken, ed., supra note 42.

58. See International Educational Development/Humanitarian Law Project, Written Statement Submitted to the UN Commission on Human Rights, 53rd Session (1997), which addressed the question of the status of the LTTE in Sri Lanka. The brief emphasized: "[a] fundamental principle is that combatants in a war are entitled to combatant status ... this status is inconsistent with a label of 'terrorist.' A terrorist has neither combatant status nor the right to engage in combat." < www.webcom.com/ 
hrin/parker.html> at para. 5 .

59. C. Greenwood, International Humanitarian Law (Laws of War): Revised Report for the Centennial Commemoration of the First Hague Peace Conference 1899, May 1999, at para. 3.10.

6o. Whether a conflict is characterized as international or internal is relevant for two reasons: In an international conflict there is a right to armed resistance; there is also concomitant responsibility, as all violations of IHL will be subject to prosecution as universal jurisdiction offences. The traditional approach to the classification of conflict focuses on the technical status of the parties, while another approach has developed that focuses on the general process of armed conflict and the presence of various "internationalizing" elements. Subject to some interpretive debate, an internal conflict becomes international when a "people" face conditions of colonialism, alien occupation, or racism, or the non-state party is recognized as a belligerent (either outside the state or by the established government), or a foreign state participates in the armed conflict. Many states will resist characterizing a liberation group as a "people" and their struggle as an "international" conflict, as it represents an incursion on sovereignty. As noted by Chadwick, a series of successful liberation wars has "led to alterations in common understanding regarding which 'Peoples' are entitled to assert claims for self-determination, and to use force to achieve their rights." Chadwick, supra note 53 at 4, 64 .

61. As an expert witness in a Canadian immigration security case, discussed infra, Falk characterized the right of self-determination as "an emerging norm of customary international law that depends for its clarification and assessment upon the specific context within which the claim is being made." Minister of Citizenship and Immigration and Solicitor General of Canada v. Suresh, DES-3-95 (T.D.), Transcript vol. 48, 3 Feb. 1997, at 33-34, 43-47; See also, E.P. Syquia, "Dr. Jean Pictet and International Humanitarian Law," Studies and Essays (The Hague, Boston: Martinus Nijhoff, 1984); T. Meron, "War Crimes in Yugoslavia and the Development of International Law" (1994) 88 AJIL 78; A. Cassese, Self-Determination of Peoples: A Legal Reappraisal (Cambridge: Cambridge University Press, 1995); P. Malanczuk, "Self-Determination and the Use of Force" in P.J. Van Krieken, ed., supra note 42 at 263-278; J.J. Paust et al., supra note 19 at 803-833; Declaration on Principles of International Law and Friendly Relations Among States, 1970; un General Assembly Resolution 3103 (XXVIII) 12 Dec. 1973.

62. Article 51 of the Charter of the United Nations, 1945, enshrines the "inherent right of individual and collective self-defence" in the face of armed attacks against member states of the United Nations.

63. Geneva Conventions Act, R.S.C. c. G-3, as am. S.C. 1990, c.14.

64. In proceedings before the UN Commission on Human Rights, the government expressed the view that the right of selfdetermination belonged to indigenous peoples as well as other collectivities and that the right is "... expanding to include the concept of an internal right for groups living within existing states that respect the territorial integrity of states ..." Statement of the Canadian Delegation to the un Commission on Human Rights, 21 Oct. 1996-1 Nov. 1996.
65. A. Cassese, supra note 37 at 7.

66. Ibid., at 123.

67. Terrorist Financing Convention, supra note 26, art. 21.

68. S. Bell, "Canada to Outlaw Fundraising for World Terrorism," National Post, 30 Dec. 1999.

69. W. Elcock, Submission to the Special Committee of the Senate on Security and Intelligence, 24 June, 1998, at 11.

70. International Convention for the Suppression of Financing of Terrorism, 1999, art. 2 (a).

71. Ibid., art. 2.1(b). Hathaway and Harvey suggest that this section may provide a conceptual basis for a more general definition of "terrorism," a project to which the UN General Assembly remains committed. J.C. Hathaway and C.J. Harvey, "Framing Refugee Protection in the New World Order" (2001) 34(2) Cornell Int'l L.J. n. 46.

72. The government also has never initiated prosecutions of alleged torturers in the refugee population, despite the specific obligation to do so in the Convention against Torture and the Criminal Code. Denying safe haven through deportation continues to be the government's preferred strategy.

73. Ibid., art.2.1

74. Ibid., art.2.5

75. See G.S. Goodwin-Gill, The Refugee in International Law, and ed. (Oxford: Oxford University Press, 1996) at 95-114; S.D. Amarasinha and M. Isenbecker, "Terrorism and the Right to Asylum under the 1951 Convention and the 1967 Protocol Relating to the Status of Refugees: A Contradiction in Terms, or Do Opposites Attract?" (1996) 65 Nordic Journal of International Law 223 at 228; and Ramirez v. Minister of Employment and Immigration [1992] 2 F.C. 306 (C.A.), discussed infra, with respect to complicity in the context of refugee exclusion under the Convention (and Canadian law).

76. Ibid., art. 14. This limitation, known in extradtion law as the "political offence exception," is also found in the European Terrorism Convention. For a discussion of the application of the political offence exception in the context of asylum and terrorism, see. J.C. Hathaway and C.J. Harvey, supra note 71.

77. J.C. Hathaway, The Law of Refugee Status (Toronto: Butterworths, 1991) at 176-179.

78. D. Stasiulus and N. Yuval-Davis, eds., Unsettling Settler Societies, Articulations of Gender, Race, Ethnicity and Class (London: Sage Publications, 1995) at 23-24.

79. S.C. 1872,35 Vict. Ch. 28 , s.10.

8o. S.C. 1910 , Edw. VII, ch. 27 , s. 41 .

81. Ibid., s. 23.

82. N. Kelly and M. Trebilcock, The Making of the Mosaic: A History of Canadian Immigration Policy (Toronto: University of Toronto Press, 1998) at 181-82, 207-209. See also, D.H. Avery, "Dangerous Foreigners": European Immigrant Workers and Labour Radicalism in Canada, 1896-1932 (Toronto: McClelland \& Stewart, 1979) at 87; and J. W. St. G. Walker, "Race," Rights and the Law in the Supreme Court of Canada (Canada: The Osgoode Society for Canadian Legal History and Wilfrid Laurier Press, 1997) at 250.

83. Canada v. Dueck (T.D.) T 938-95 (1998) at n.144. A fascinating record of post-war immigration security procedures is con- 
tained in this Federal Court decision rejecting the government's application to revoke Dueck's citizenship.

84. R.S.C. 1952 , ch. 325.

85. Ibid., ss. 5 (1), 19 (a).

86. S.C. $1966-67$, ch. 90

87. See A. Brannigan and Z. Lin, “'Where East Meets West': Police, Immigration and Public Order Crime in the Settlement of Canada from 1896 to 1940" (1999) 24 Canadian Journal of Sociology 87 at 91 .

88. National policies on the admission and exclusion of foreigners are typically characterized as central aspects of state sovereignty. In this context, immigration has been characterized as a privilege rather than a right. See. R. Plender, International Migration Law, $2^{\text {nd }}$ ed. (Dordrecht, Netherlands: Martinus Nijhoff, 1988). By affording individuals the right to seek and enjoy asylum, the Refugee Convention represents a significant incursion on state sovereignty. However, neither the Convention nor other international instruments impose an unequivocal obligation on states to admit or host refugees. This apparent contradiction is addressed in part through the application of non-refoulement provisions, discussed below.

89. R. Whitaker, supra note 10 at 419-420.

90. S.C. 1976-77, ch. 52.

91. See Immigration Act, ss. $3(\mathrm{f}),(\mathrm{d}),(\mathrm{i})$, and (j).

92. Sections 32 and 33 of the Refugee Convention set out the security and public order exceptions to the obligation of nonrefoulement, an obligation described as the cornerstone of international refugee protection. See G. Goodwin-Gill, supra note 75 at 167-171. The Convention stipulates that these exceptions must be applied in accordance with "due process of law"-language that the new Act did not incorporate and thatexisting procedures arguably lack. The Act also failed to incorporate many other protections afforded in the Convention.

93. See ехсом Conclusions No. 6 (xхviII) on Non-Refoulement and No. 7 (xxviII) on Expulsion (1977). Established in 1951, the functions of the UNHCR include the promotion of international standards for the treatment of refugees. Consensus reached by its Executive Committee in annual sessions are expressed in the form of Conclusions. Strictly speaking, these Conclusions are not binding on states, but they comprise a form of "soft law," which contribute to the development of international refugee law. The UNHCR's interpretation of the exclusion clauses is consistent with the general rule that exceptions to human rights standards should always be interpreted restrictively. Art. 31 of the Vienna Convention on the Law of Treaties 1969 also requires that interpretation be made in "good faith" and in light of a treaty's object and purpose. See also G. Stenberg, Non-Expulsion and Non-Refoulement: The Prohibition against Removal of Refugees with Special Reference to Articles 32 and 33 of the 1951 Convention Relating to the Status of Refugees, Swedish Institute of International Law, Studies in International Law, vol. 9 (Uppsala: IUstus Forlag, 1989) at 165 and 220-221; and Pushpanathan v. Canada [1998] 1 S.C.R. 982, in which the Supreme Court confirmed that provisions that disentitle a person to human rights protection are to be read narrowly and restrictively. This caution was articulated most recently in
UNHCR, Comments on Bill C-31, 11 July 2000, available on the website of the Canadian Council for Refugees $<$ www.web.net/ $\sim \mathrm{ccr}>$.

94. As noted by Kiss, national security has a very specific meaning in international law, which is distinct from public safety or order. As it is used in the Covenant on Civil and Political Rights to limit specified rights, national security "means the protection of territorial integrity and political independence against foreign forces or threats of force. It would probably justify limitations on particular rights of individuals or groups where the restrictions were necessary to meet the threat or use of excessive force. It does not require a state of war or national emergency, but permits continuing peacetime limitations, for example, those necessary to prevent espionage or to protect military secrets." A. Kiss, "Permissible Limitations on Rights," in L.K. Henkin, ed., The International Bill of Rights (New York: Columbia University Press, 1981) at 297.

95. Immigration Act, s. 19(1) (e) and (f).

96. Ibid., s. 19(1)(g).

97. Ibid., s. 19(1)(j).

98. See S. Aiken, "Racism and Canadian Refugee Policy" (1999) 18:4 Refuge 2.

99. Commission of Inquiry Concerning Certain Activities of the Royal Canadian Mounted Police, Freedom and Security Under the Law, Second Report, vol. 2 (Ottawa: Minister of Supply and Services Canada, 1981).

100. Ibid., at 823 .

101. Ibid., vol. 1, at 43-44.

102. Ibid., at 436 .

103. Gorlick, supra note 8 at 77.

104. CSIS Act, R.S. 1985, c. C-23, as am. by R.S., 1985 c.1 (4th Supp.). s. 2 (a), (b), (c), (d).

105. See, e.g., M.J. Leddy, supra note 17. 82. See SIRC, Annual Report 1997-1998 (Ottawa: Minister of Supply and Services, 1998) at 912.

106. SIRC File Nos. $1500-82,83$, supra note 17.

107. SIRC Annual Report 1999-200o, supra note 17, Section 1, at 17. 108. Ibid.

109. See, A. Thompson, "Not Our policy to Coerce Refugees," The Toronto Star, 1 May 1998; "More Refugees Come Forward with Claims of csis Threats," The Toronto Star, 23 April 1998; "Spy Agency Tactic under Fire," The Toronto Star, 4 April 1998; "How a Spy is Hired: Case of Tamil Refugee Claimant Shines Light on How csis Operates," The Toronto Star, 20 Jan. 1996.

This has been difficult to "prove" for the purposes of formal complaints, as screening interviews are not tape recorded. Certain csis officers have been unable to recall such remarks when subsequently requested to address concerns on the manner in which an interview was conducted. Although complaints of this nature were raised in the cases of S.G. and S.D., the Chair was unable to substantiate them with regard to the complainants themselves. The sIRC reports recommended that all security interviews should be recorded and retained until a decision on immigration status is determined by the Department of Citizenship and Immigration. See SIRC File No. 1500-83 supra note 17 at 32. 
110. Outlawing an Ancient Evil: Torture, Convention against Torture and Other Cruel, Inhuman or Degrading Treatment or Punishment, Initial Report of Canada (Ottawa: Multiculturalism and Citizenship Canada, 1989) at 1. The Committee against Torture is a body of ten experts who are elected by states but serve in their personal capacity to monitor state compliance with the Treaty. Every four years Canada must submit a performance report on measures it has adopted to effect its treaty commitments and defend the report before the Committee. Canada submitted in its third report in September 1999, which the Committee evaluated in November 2000. Note that Canada has recognized the Committee's competence to receive and consider communications alleging violations of the Treaty, from individuals subject to its jurisdiction, as well as other states.

111. Art. 3 of the Convention against Torture and Other Cruel, Inhuman or Degrading Treatment or Punishment states:

1. No State Party shall expel, return ("refouler") or extradite a person to another State where there are substantial grounds for believing that he would be in danger of being subjected to torture.

2. For the purpose of determining whether there are such grounds, the competent authorities shall take into account all relevant considerations including, where applicable, the existence in the State concerned of a consistent pattern of gross, flagrant or mass violations of human rights.

112. The Criminal Code, s. 269, criminalizes torture, defined in the same terms as art. 1 of the Сат. The government has suggested that the "post claim review" available to refused refugee claimants implements Canada's obligations under art. 3 of the CAT. However, people at risk of torture are not eligible to apply if they never made a refugee claim, if they were found ineligible to make a refugee claim, if their refugee claim was found to have "no credible basis," if they have been designated as a security risk or public danger, or if they fail to apply within fifteen days of a negative refugee decision. For those who are eligible to apply, the complex definition is not consistent with art. 3, requiring, for example, that the risk apply in every part of the country of deportation destination. Decisions are made on paper submissions, without any oral hearing, by a relatively junior immigration official. A positive decision on a discretionary "humanitarian and compassionate" review (which requires a $\$ 500$ application fee for an adult and \$100 for a minor) will not overcome security inadmissibility. In rare cases, a "minister's permit" may be issued to individuals who are inadmissible for security reasons but for whom there are extraordinary circumstances to grant a temporary right to remain in the country. Generally evidence of successful establishment is required, in addition to any personal risk associated with return. In 1999 just four permits were issued in security cases. There is no automatic stay of removal in cases where decisions are pending, so individuals are often removed even though a decision has not been made on their case. See Annual Report to Parliament on Minister's Permits Issued in 1999 <www.cic.gc.ca/english/pub/ permits9ge.html>; and Canadian Council for Refugees, Submission to UN Human Rights Committee in preparation for the examination of Canada on its compliance with the Cov- enant on Civil and Political Rights, March 1999, <www.web.net/ $\sim \mathrm{ccr} /$ iccpr.htm\#top $>$.

113. Re Singh and Minister of Employment and Immigration and 6 other appeals [1985] 1 S.C.R. 177.

114. Immigration Act, s.38.1. See ss. 39-40.1 for details of the procedures.

115. Ibid., s. 19(1)(e)(iii).

116. Ibid., s. 19(1)(e)(iv)(C).

117. Ibid., s. 19(1)(f)(ii), (iii)(B).

118. Hon. D. Lewis, Solicitor General, House of Commons Debates,132:163 at 12533, 22 June, 1992.

119. Immigration Act, s. 19 (1)(e)(iv)(A);(f)(iii)(A).

120. Ibid., s.46.01(1)(e)(ii).

121. Note that $s .52$ of the Immigration Act provides that persons subject to deportation may be allowed to leave "voluntarily" and to select the country to which he or she wishes to go, unless the Minister directs otherwise (emphasis added). A person who is not permitted to leave voluntarily will be removed to one of four destinations: (1) the country from which the person came to Canada; (2) the country in which the person last permanently resided before coming to Canada; (3) the country of which the person is a national or citizen; or (4) the country of that person's birth. If none of these countries is willing to receive the person, then the Minister may select any country willing to accept him or her. With the approval of the Minister, the person may select (within a reasonable period of time) any country willing to grant admission (emphasis added).

122. J. Shields, Parliamentary Secretary to the Minister of Employment and Immigration, House of Commons Debates, 132:163 at 12504-5, 22 June 1992.

123. Interview with A. Brouwer, Maytree Foundation, 22 November 2000. See also SIRC Files No 1500-82, 83; and SIRC Annual Report 1999-200o, supra note 17.

124. In the U.K., a new terrorism law authorizes the Secretary of State to proscribe organizations involved in either international or domestic terrorism, but such designations require the approval of both Houses of Parliament. In addition, the legislation sets out a procedure to be followed by an organization that wishes to challenge the designation or an affected individual. After an initial application to the Secretary of State, there is a right of appeal to the Proscribed Organizations Appeal Commission with provisions for representation, and a further appeal on points of law to the Court of Appeal in London. M. Barber, House of Commons Library (U.K.) Research Paper 99/ 10113 Dec. 1999, "The Terrorism Bill: Bill 10 of 1999-200o," $<$ www.parliament.uk>. In the U.S., the Antiterrorism and Effective Death Penalty Act, 1996, empowers the Secretary of State to designate "foreign terrorist organizations." The purpose of the power is to deny material support to the designated organization and to seize its assets. It is not a criminal offence to belong to a designated organization, but membership is grounds for deportation and denial of entry for non-citizens. According to the Immigration and Nationality Act, an "alien terrorist" is an alien who contributes in any of several specified ways to any of several designated unlawful acts. The list of acts includes hijacking, sabotage, hostage taking, assassination, other miscel- 
laneous crimes, and a "threat, attempt, or conspiracy" to commit any of the enumerated acts. The U.S. State Department currently includes thirty non-state organizations on its list of terrorists and seven governments.

125. The identification of a general principle of international law as jus cogens provides it with the status of "higher law." Art. 53 of the Vienna Convention on the Law of Treaties sets out the jus cogens rule, indicating that a treaty is void if it conflicts with a peremptory norm of general international law, namely a norm that is "accepted and recognized by the international community of states as a whole as a norm from which no derogation is permitted and which can be modified only by a subsequent norm of general international law having the same character." There is some disagreement on the precise scope and content of jus cogens. See Sir I. Sinclair, The Vienna Convention on the Law of Treaties, 2nd. ed. (Manchester: University Press, 1984) at 18. With regard to the prohibition on torture, see, J.H. Burgers and H. Danelius, The United Nations Convention against Torture: A Handbook on the Convention against Torture and Other Cruel, Inhuman or Degrading Treatment or Punishment (Dordrech, Netherlands: Martinus Nijhoff Publishers, 1988) at 12 and 176; Re Pinochet Ugarte [1999] H.L.J. No. 12 (24 Mar. 1999); Prosecutorv. Furundzija (10 Dec. 1998), Case No.: IT-95-17/1-T 10 ; and on the principle of non-refoulement, see G.S. GoodwinGill, supra note 75; K. Parker and L.B. Neylon, "Jus Cogens: Compelling the Law of Human Rights" (1989) 12 Hastings International \& Comp. L. Rev. 411 at 435-436; G. Stenberg, supra note 93 at 278-280; Cartagena Declaration on Refugees, 1984-85 Report of the Inter-American Commission on Human Rights, Conclusion 5 at 177-182; and 1988 Report of the United Nations High Commissioner for Refugees, UN GAOR, 4oth Sess., Supp. No. 12 at 6, UN Doc. A/40/12 (1985).

126. R. v. Schmidt [1987] 1 S.C.R. 500 at 522 and 532; Kindler v. Canada [1991] 2 S.C.R. 779 at 832 and 851.

127. EXCOM Conclusion No. 79 (XLVII) General Conclusion on International Protection (1996), para. (j).

128. In 1997 and 1998 Canada carried out deportations in contravention of requests from the Committee against Torture (Tejinder Pal Singh v. Canada) and the Inter-American Commission on Human Rights (Roberto San Vicente v. Canada). See Amnesty International, "Refugee Determination in Canada: The Responsibility to Safeguard Human Rights," Response to Government of Canada's White Paper, February, 1999.

129. In 1995, in a climate of rising hysteria about "immigrant criminals," the government implemented Bill c-44, introducing significant changes to the rights of refugees and long-term permanent residents. Pursuant to s. 7o(5) of the amended Act, individuals who are classified as a "danger to the public" may be arrested and held indefinitely pending deportation under an opinion issued by the Minister. The threshold for consideration of the issuance of a danger to the public opinion is conviction for a criminal offence carrying a maximum penalty of ten years or more. The potential sentence, rather than the actual sentence imposed by the court in the particular circumstances of the case, is the determinative factor. Under the new scheme there is no right of appeal or an oral hearing, and procedures largely resemble those used in security cases with the exception of more complete disclosure in the absence of a need to protect intelligence information.

130. In 1998 the House of Commons Standing Committee on Citizenship and Immigration issued a report in which the question of deporting people in contravention of formal requests by international human rights bodies was considered. The Committee indicated that " $[\mathrm{w}] \mathrm{e}$ are unwilling to recommend that deportation should never occur in these cases, because there could be extreme situations that would shock Canadians should the government not remove an individual." It was recommended that "great caution" should be exercised in such cases and that deportation proceed "only for the most compelling reasons." Standing Committee on Citizenship and Immigration, Immigration Detention and Removal, June 1998, at 19; Recommendation 28. In its formal response the government agreed that "such caution is needed" but made no commitment to comply with the requests of international human rights bodies. Government response to the Report of the Standing Committee on Citizenship and Immigration, Immigration Detention and Removal. See also, Canadian Council for Refugees, Comments on Canada's Compliance with the Convention against Torture, Prepared for the United Nations Committee against Torture, November 2000.

131. UN G.A. Res. 51/210 (16 Jan. 1997), para. 3; see also, Declaration on Measures to Eliminate International Terrorism, U.N.G.A. Res. 49/60 (9 Dec. 1994) Annex, para. 5 (f).

132. In the case of Paez v. Sweden the un Committee against Torture directly addressed the scope and nature of article 3 of the CAT and its relationship with the Refugee Convention. This case involved Sweden's proposal to deport a failed refugee claimant who was a member of the Shining Path and had admitted to handing out home-made bombs that were used against police. The Committee rejected Sweden's contention that the "terrorist character" of the Shining Path could justify the deportation, noting that "the nature of the activities in which the person concerned engaged cannot be a material consideration when making a determination under article 3 of the Convention." Committee against Torture, Communication No. 39/1996, UN Doc.A/52/44 (1997) at 94. See also Khan v. Canada, Committee against Torture, Communication No. 15/1994, UN Doc. A/50/ 44 (1995) at 46; International Covenant on Civil and Political Rights, art. 7; and un Human Rights Committee General Comment 20 (article 7) UN Doc. CCPR/C/21/Add.3: "State parties must not expose individuals to the danger of torture or cruel, inhuman or degrading treatment or punishment upon return to another country by way of their extradition, expulsion or refoulement" (at para. 9). The European Court of Human Rights has developed a similar protection against non-refoulement. See, e.g., Chahal v. U.K. (1996), Reports of Judgments and Decisions, 1996-V, paras. 72-82; 23 EHRR, 1997, at 413; also, R. Plender and N. Mole, "Beyond the Geneva Convention: Constructing a de facto Right of Asylum from International Human Rights Instruments" in F. Nicholson and P. Twomey, eds., supra note 9, 81-105.

133. Second Optional Protocol to the International Covenant on Civil and Political Rights, G.A. res. 44/128, annex, 44 UN GAOR Supp. 
(No. 49) at 207, UN Doc. A/44/49 (1989). Despite the fact that the death penalty is not imposed in Canada, the Supreme Court of Canada has confirmed the constitutionality of extradition orders against non-citizens in cases where the fugitives could be subject to the death penalty in their country of origin. The constitutionality of surrendering Canadian citizens to face the death penalty in the United States is pending decision in the Supreme Court. See Kindler v. Minister of Justice, [1991] 2 S.C.R. 779; Reference Re Ng Extradition (Canada), [1991] 2 S.C.R. 858; and Minister of Justice v. Burns and Rafay, S.C.C. No. 26129.

134. Art. 8 of 1961 Convention on the Reduction of Statelessness; and ехсом Conclusion No. 78 (xuvi) Conclusion on the Prevention and Reduction of Statelessness and the Protection of Stateless Persons (1995). Although the Convention does not directly address deportation, it imposes on states an obligation to ensure that the right to nationality is protected and that state action does not lead to statelessness. See also art. 12. 4 of the International Covenant on Civil and Political Rights.

135. The right to family life is inscribed in arts. 17 and 23 of the International Covenant on Civil and Political Rights as well as in arts. $v$ and vi of the American Declaration on the Rights and Duties of Man; the Convention on the Rights of the Child imposes a direct obligation on states to ensure that the "best interests" of children are a primary consideration in all actions concerning children. See Baker v. Canada [1999] 2 S.C.R. 817; and R. Plender and N. Mole, supra note 132 at 97-101.

136. See, e.g., the evidence provided by former ambassadors $M$. Collacott and W. Bauer before the Standing Committee on Citizenship and Immigration on 1 Dec. 1999, on the Committee's Study "Refugee Protection and Border Security," <www.parl .gc.ca/InfoComDoc/36/2/CIMM/Meetings/Evidence/ cimmevo7-e.htm>.

137. R. Tassé, Removals: Processes and People in Transition, Report prepared for Citizenship and Immigration Canada, February 1996; Legislative Review Advisory Group, "Not Just Numbers, A Canadian Framework for Future Immigration" (Minister of Public Works and Government Services Canada, 1997). In January 1999 the government released its long awaited white paper Building on a Strong Foundation for the Twenty First Century: New Directions for Immigration and Refugee Policy and Legislation <www.cic.gc.ca>. The document proposed reforms in broad terms without indicating concrete measures to be pursued. For relevant commentary see the special issue "Not Just Numbers and New Directions: Implications for Canadian Refugee Policy" (1999) 18:1 Refuge.

138. Bill c-31, The Immigration and Refugee Protection Act, ss. 30(1) (c) and (f).

139. See, e.g., The Report of the Special Senate Committee on Security and Intelligence, Jan. 1999, ch. 2 at 11 <www.parl.gc.ca/36/1/ parlbus/commb.../com-e/secu-e/repsecintjan99-ehtm $>$; Legislative Review Advisory Group, supra note 127, Recommendation 138; and the Security Intelligence Review Committee, Annual Report 1997-1998, Section 1 at 10 <www.sirc-csars.gc.ca/ ar9798_e.html>.

140. See Immigration Act, ss. 39.1,39.2 and 40.

141. Ibid., s. 40.1.
142. "In Flux but not in Crisis," Report of the Special Committee on the Review of the csis Act and the Security Offences Act (Ottawa: Queen's Printer, 1990); and see Gorlick, supra note 8 at 79. In response to Bill C-31, sIRC expressed concern, noting its "unique expertise in acting as a competent tribunal to handle appeals related to intelligence and security matters-a capacity that Parliament intended it to have ... this proposal would remove important existing safeguards in the activities of csis that could have a serious negative impact on national security, on individual rights, or on both." SIRC Annual Report 1999-20oo, supra note 17 at 2.

143. Bill C-31, supra note 119, ss. 71, 72, 75, and 108. For critical commentary see briefs submitted by UNHCR, Comments, supra note 94; Canadian Council for Refugees; Maytree Foundation $<$ www.web.net/ ccr $>$.

144. R. Romonow, J. Whyte and L. Leeson, Canada . . Notwithstanding: The Making of the Constitution 1976-1982 (Toronto: Carswell/Methuen, 1984) at 218; M. Mandel, The Charter of Rights and the Legalization of Politics in Canada (Toronto: Thomson Educational Publishers, 1994) at 68-74; and P. Russell, "The Political Purposes of the Canadian Charter of Rights and Freedoms" (1983) 61 Can. Bar Rev. 30 at 49.

Sharryn J. Aiken is a lecturer at Osgoode Hall Law School. The author gratefully acknowledges Barbara Jackman for her generosity and assistance. The author also thanks Janet Dench, Brian Gorlick, Audrey Macklin, and Lorne Sossin for their helpful comments on an earlier draft. This paper is dedicated to Sami Durgun and Suleyman Goven, whose struggles for justice in Canada remain an inspiration.

(C) Sharryn J. Aiken, 2001. This open-access work is licensed under a Creative Commons Attribution-NonCommercial 4.0 International License, which permits use, reproduction and distribution in any medium for non-commercial purposes, provided the original author(s) are credited and the original publication in Refuge: Canada's Journal on Refugees is cited. 